\title{
THE EFFECTIVENESS OF ELECTRONIC WHITEBOARDS ON STUDENTS' READING SKILLS
}

\author{
${ }^{1,2}$ Jusmin HJ Wahid, ${ }^{1}$ Iwan Irawan, \& ${ }^{1}$ Sumiati Tidore \\ ${ }^{1}$ Faculty of Education, Muhammadiyah University of North Maluku, Indonesia \\ ${ }^{2}$ Corresponding Author Email: j.hj.wahid2010@gmail.com
}

\begin{tabular}{|c|c|}
\hline Article Info & Abstract \\
\hline $\begin{array}{l}\text { Article History } \\
\text { Received: August } 2020 \\
\text { Revised: September } 2020 \\
\text { Published: January } 2021\end{array}$ & \multirow{2}{*}{$\begin{array}{l}\text { Technology has become a demand for students to master their reading skills. } \\
\text { Technology right now plays an important role in the teaching and learning } \\
\text { process. The lecturer and teachers are needed technology to improve their } \\
\text { material and make their teaching are effective. It was expected that to apply the } \\
\text { electronic whiteboard itself can use by the lecturer to design better ways for the } \\
\text { students to acquire important information. It is realized that the fourth-semester } \\
\text { students at the English Department of Khairun University are needed as much } \\
\text { information on the electronic whiteboard as possible to improve their reading } \\
\text { skills. This research is an experimental research that was held at the English } \\
\text { Program at Khairun University Ternate. The experimental research involves two } \\
\text { groups of students, they are the experimental group and the control group. The } \\
\text { researcher used the English Program's fourth-semester students at Khairun } \\
\text { University Ternate as a research sample. The result of the t-test in the } \\
\text { experimental class shows that the mean score of the pre-test was } 74.90 \text { and the } \\
\text { means score of the post-test was } 81.90 \text {. It shows that electronic whiteboards in } \\
\text { the experimental class experienced significant improvement in students reading } \\
\text { skills. Then, the standard deviation in the post-test was } 5.58 \text { and the standard } \\
\text { deviation in the pre-test was } 4.38 \text {. It could be concluded that the students get } \\
\text { significant progress in their reading skills after applying the electronic } \\
\text { whiteboard. }\end{array}$} \\
\hline $\begin{array}{l}\text { Keywords } \\
\text { Electronic Whit } \\
\text { Reading Skills; }\end{array}$ & \\
\hline
\end{tabular}

How to cite: Wahid, J. H. J., Irawan, I., \& Tidore, S. (2021). The Effectiveness of Electronic Whiteboards on Students' Reading Skills, JOLLT Journal of Languages and Language Teaching, 9(1), 69-76. DOI: https://doi.org/10.33394/jollt.v\%vi\%i.2953

\section{INTRODUCTION}

In the 4.0 era right now, technology has become a demand for students to master their reading skills. Technology in ELT contexts plays an essential role in the teaching and learning process. Many researchers have been conducting studies dealing with using technologies or learning tools such as Moodles (Angelini \& Garcia-Carbonell, 2018), Mobile applications (Haerazi, Utama, \& Hidayatullah, 2020), and Google classroom (Oader \& Arslan, 2019) in ELT contexts. Therefore, teachers need proper learning tools to improve their teaching material and make their teaching effective.

In the learning process, especially English language learning, students need a suitable technology to improve their reading skills. One of the most important technology is electronic whiteboard to assess the whole process of English language learning. The development of information technology contributes a great deal to the English language teaching and learning process. Electronic whiteboard is a vital tool to use in teaching reading skills. Le Breuilly (2004) Teachers could allow pupils to draw the image and characters from a reading text on the IWB to assist in reading comprehension. This activity tends to increase pupils' selfconfidence and cognitive skills. Hall \& Higgins (2005), the interactivity of IWB enhances pupils' interest to learn by presenting a variety of multimedia elements especially visual 
image. Elliot (2003) stated that IWB enables smooth transition from one topic to another. IWB also improves peer reading and improves communications between pupils and teachers (Yunus et al., 2012).

The use of various learning tools becomes challenging for EFL students. In practice, some of students feel difficulty in learning by technology (Nicole et al., 2018). They are very late to consumption the information from the lecturer by technology. It is because they are difficult to operate technology itself. It is needed for the lecturer or teacher to guide them to mastery the technology and make them feel enjoyable in the teaching and learning process (Mustafa et al., 2019). In the teaching and learning process, especially in reading skills, those are some problems namely, the lack of understanding the meaning of the reading text, the lack of vocabulary, and the lack of students' interest it is because of the learning tools used by the lecturers are still unproper with their teaching materials. In line with this, the researcher is interested in using electronic whiteboards to improve students reading skills.

Al-Saleem (2012) showed that an interactive Whiteboard is a touch-sensitive screen that works in conjunction with a computer and a projector. It is a presentation device that interfaces with a computer. The computer images are displayed on the board by a digital projector, where they can be seen and manipulated. Users can control software both from the computer and from the board. In addition, Serin (2015) in Zevenbergen \& Lerman (2008) suggested that IWB is an innovation that is gaining considerable presence in many contemporary classrooms and teaching has become very productive with it. Compared with traditional instruction, technology-based instruction impacts on classroom management which holds an important place in education as it affects the learner achievement. However, IWB is a useful device that can enhance whole-class teaching which is a key factor in classroom management.

Based on the previous studies, the electronic whiteboard is a technology that helps students improve their learning style and make them enthusiastic in the teaching and learning process. It is in line with Al-Faki et al. (2014) who state that interactive Whiteboard (IWB) is a large touch-sensitive display unit, connected to digital data projectors and computers. IWB functions as an interactive board, computer screen (monitor), and mouse at the same time. Users can change the monitor to the whiteboard and vice versa (vs.), or use them at the same time. Users can use their finger, special electronic pen (stylus), pointer, or a pen to operate the board and/or control computer icons. All the works, which would be done on IWB, could be saved and revisited for revision, warm-up, etc. It evens the handwriting of the teacher's and/or learners' could be stored and are accessible at any time.

Bojovic (2010) said that reading skill is a cognitive ability that a person can use when interacting with the written text. In the taxonomies given in the following paragraph, some skills seem more inclusive than others. Reading skills involve: identifying word meaning, drawing inferences, identifying writer's technique, recognizing mood of passage, finding answers to questions. Reading skills can also include: recognizing the script of language; deducing the meaning, use of unfamiliar lexical items; understanding explicitly and nonexplicitly stated information, conceptual meaning, the communicative value of sentences, relations within the sentences and between parts of a text through lexical cohesion devices; recognizing indicators and the main point of information in discourse; distinguishing the main idea from supporting detail; selective extraction of relevant points from the text; basic reference skills; skimming, scanning, transcoding information from diagrams or charts.

Reading is a tool of communication in written language through the text form. It is the most efficient way to gain information about many aspects of life, including science and technology. By reading, people can absorb some information. Reading has a very important role and becomes a daily necessity for every person who wants to acquire whatever required information. Reading is an essential skill for learners of English as a foreign language. For 
most learners, it is the most essential skill to master to ensure success learning English in any content class where reading in English is required.

In the previous research, It can be concluded that IWB enhanced pupils' EFL reading comprehension skills. Data showed that integration of IWB provided pupils with resourceful learning experience which increased their excitement to learn, enhanced their classroom engagement, encouraged independent learning and promoted seriousness in reading. Integration of IWB also improved pronunciation and vocabulary acquisition among pupils. To conclude Research Question 1 (RQ1), IWB in the classroom enabled teachers to teach reading more effectively and maintain pupils' participation in the classroom.

\section{RESEARCH METHOD \\ Research Design}

This study aimed to investigate the effectiveness of using the electronic whiteboards as learning tools to improve students' reading skills at fourth semester students in the English Department of Khairun University. This study is quantitative study to know students' competence in using Electronic whiteboards to improve their reading skills. The researcher uses a randomized pre-test and post-test design in his research and used SPSS-16 to analyze the data. Creswell (2008: 152) population (or the sampling frame) is a group of individuals (or a group of organizations) with some commons defining characteristics that the researcher can identify and study. Within this target of population, the researcher then selects a sample for the study. The sample is a subgroup of the target population that the researcher plans to study for generalizing about the target population. Research population is all students of fourthsemester; consists of two classes, namely class A consisting of 44 students and B consists of 42 students. Then, the researcher used random sampling to take the sample. To gain the data, the questionnaires and reading tests were distributed to the research sample. The questionnaires consist of 15 questions to know students' perception of electronic whiteboard on students' reading skills.

\section{Data Analysis}

The technique of data analysis used the descriptive analysis and inferential analysis, the descriptive analysis was aimed at describing the reading test, the form of reading test which is used in pre-test and post-test. The description includes standard deviation, mean, maximum score, and frequency distribution. Besides, the inferential analysis aims to know that the research data are normal or no and the researcher used t-test to know the differences between experimental and control group scores. The data indicated that the use of Whiteboard was effective to enhance students' reading skills at the fourth-semester of English department.

\section{RESEARCH FINDINGS AND DISCUSSION Research Findings}

This article explores the research finding and discussions that answering the questions of the research. The research question is what the electronic whiteboard has an effect on students' reading skills. To know the effect of the electric whiteboard, this study divided students into two classes. It can be seen in Table 1 that show the results of students' reading skills in pre-test and post-test.

Table 1

The result of students' competence in the control class Paired Sample Statistic in Control Class

\begin{tabular}{llllc} 
No & Interval & Mean & $\mathrm{N}$ & $\begin{array}{c}\text { Std. } \\
\text { Deviation }\end{array}$ \\
\hline 1. & Pre-test & 65.30 & 20 & 4.13 \\
\hline 2. & Post-test & 70.25 & 20 & 6.43
\end{tabular}


The total number of students involved in the process of control class was 20 . The data showed that the information in the post-test of electronic whiteboard got better with the average mean score was 70.25 and the results of pre-test got the score was 65.30 . Then, the standard deviation in post-test 6.43 and the standard deviation of pore-test 4.13 . It could be concluded that the electronic whiteboard improves students' competence in the teaching and learning process. It can be seen in Table 2 as follows.

Table 2

\begin{tabular}{llccc} 
No & $\begin{array}{c}\text { The Result of Students' Competence in the Experiment Class } \\
\text { Interval }\end{array}$ & Mean & N & $\begin{array}{c}\text { Std. } \\
\text { Deviation }\end{array}$ \\
\hline 1. & Pre-test & 74.90 & 20 & 4.38 \\
\hline 2. & Post-test & 81.90 & 20 & 5.58
\end{tabular}

Based on the table above, the researcher could explain that the electric whiteboard in the post-test has significant improvement with a mean score of 81.90 among 20 students who involved in the process of the post-test itself. The results of the pre-test from the 20 students who involved in the pre-test have an average score of 74.90. Then, the standard deviation in the post-test showed that the score was 5.58 and pre test showed that 4.38. From the table above, It could be concluded that the electronic whiteboard had the best improvement to students' competence in reading skill. Meanwhile, the normality test can be seen in Table 3 as follows.

\section{Table 3}

The normality test

\begin{tabular}{llccc} 
No & Interval & $\begin{array}{c}\text { Kolmogrov- } \\
\text { Smirnov }\end{array}$ & Df & Sig \\
\hline 1. & Pre-test & 1.198 & 20 & 113 \\
\hline 2. & Post-test & 1.024 & 20 & .245
\end{tabular}

From the table above, it could be concluded that the data of pre-test and post-test were normal. The result as seen from the table above, it showed that the significant value getting higher than 0.05. It can be seen from the Kolmogrov-Smirnov table in which the significant value of pre-test was $1.024>0.05$. and post-test was $1.198>0.05$. The data showed that the score was normal.

Table 4

The Data Distribution of Pre-test in the Control Class

\begin{tabular}{lcccc} 
No & Interval & Frequency & $\boldsymbol{\%}$ & Category \\
\hline 1. & 60 & 4 & 20.0 & 20.0 \\
\hline 2. & 65 & 1 & 5.0 & 25.0 \\
\hline 3. & 66 & 1 & 5.0 & 30.0 \\
\hline 4. & 70 & 5 & 25.0 & 55.0 \\
\hline 5. & 75 & 6 & 30.0 & 85.0 \\
\hline 6. & 77 & 2 & 10.0 & 95.0 \\
\hline 7. & 80 & 1 & 5.0 & 100.0 \\
\hline 8. & 60 & & 4 & 20.0 \\
\hline Total & & 20 & 100.0 &
\end{tabular}


Table 5

The Data Distribution of post-test in the control class

\begin{tabular}{lcccc} 
No & Interval & Frequency & $\boldsymbol{\%}$ & Category \\
\hline 1. & 60 & 5 & 25.0 & 25.0 \\
\hline 2. & 65 & 9 & 45.0 & 45.0 \\
\hline 3. & 66 & 1 & 5.0 & 5.0 \\
\hline 4. & 70 & 4 & 20.0 & 20.0 \\
\hline 5. & 75 & 1 & 5.0 & 5.0 \\
\hline Total & & 20 & 100.0 &
\end{tabular}

Based on the table above, the researcher used the percentage to elaborate more about the students' scores. From the table of pre-test, it can be seen that 4 students frequently got 60 score or $20.0 \%, 1$ student frequently got score 65 or $5.0 \%, 1$ student frequently got score 66 or $5.0 \%, 5$ students frequently got score 70 or $25.0 \%, 6$ students frequently got score 75 or $30.0 \%, 2$ students frequently got score 77 or $10.0 \%$, and 1 student frequently got score 80 or $5.0 \%$. It can be stated that students' competence in using electronic whiteboard during the teaching and learning process are still low or standard. Then, it can be seen that the score in the post-test is 5 students frequently got 60 score or $25 \%, 9$ students got 65 score or $45 \%, 1$ student got 66 score or $5.0 \%, 4$ students got 70 score or $20 \%$, and 1 student got 75 score or $5.0 \%$. It can be stated that the students competence in using electronic whiteboard are midle competence.

Table 6

The Data Distribution of pre-test an experimental class by using the electronic whiteboard

\begin{tabular}{lcccc} 
No & Interval & Frequency & $\boldsymbol{\%}$ & Category \\
\hline 1. & 70 & 1 & 5.0 & 5.0 \\
\hline 2. & 75 & 3 & 15.0 & 20.0 \\
\hline 3. & 80 & 6 & 30.0 & 50.0 \\
\hline 4. & 85 & 8 & 40.0 & 90.0 \\
\hline 5. & 88 & 1 & 5.0 & 95.0 \\
\hline 6. & 95 & 1 & 5.0 & 100.0 \\
\hline Total & & 20 & 100.0 &
\end{tabular}

Based on the table above, the researcher used percentage to elaborate more about the students' scores in experiment class on the pre-test. From the table itself, it can be seen that 1 student frequently got 70 score or $5.0 \%, 3$ students frequently got score 75 or $15.0 \%, 6$ students frequently got score 80 or $30.0 \%, 8$ students frequently got score 85 or $40.0 \%, 1$ student frequently got score 88 or $5.0 \%$, and 1 student frequently got score 95 or $5.0 \%$. it can be seen that the students score at the same level. Next for post-test score 8 students frequently got 70 or $40.0 \%, 2$ students got 75 score or $10.0 \%$, 4 students got 77 score or $20.0 \%$, and 6 students got 80 or $30.0 \%$. It can be addressed that students' competence in using electronic whiteboard during the teaching and learning process is getting higher and improve their reading skills.

\section{Discussion}

Based on the the previous elaboration, from the pre-test data of the control class, it showed that the mean score was 65.30 Then, the mean score on post-test was 71.90. It means that there are any relations and good results that can be acquired after doing the two steps in this research. Meanwhile, the data in the post-test have significant improvement with mean score 81.90 who involved in the process of the post-test and the results of the pre-test have the average score of 74.90. Then, the standard deviation in post-test showed that the score was 
5.58 and pre-test showed that 4.38. It could be stated that the electronic whiteboard can improvem the students' competence in reading skills.

The data showed that 1 student frequently got 70 score or $5.0 \%, 3$ students frequently got score 75 or $15.0 \%, 6$ students frequently got score 80 or $30.0 \%, 8$ students frequently got score 85 or $40.0 \%, 1$ student frequently got score 88 or $5.0 \%$, and 1 student frequently got score 95 or $5.0 \%$. it can be seen that the students score at the same level. Next for post-test score 8 students frequently got 70 or $40.0 \%, 2$ students got 75 score or $10.0 \%$, 4 students got 77 score or $20.0 \%$, and 6 students got 80 or $30.0 \%$. It can be addressed that students' competence in using electronic whiteboard during the teaching and learning process is getting higher and improve their reading skills.

Electronic whiteboard is effective to use in teaching reading skills, it makes the students to be easy to understand the text because students were involved to analyze the sentence structures, find out difficult vocabulary, and discuss the reading comprehension. It is in line with Prasojo et al. (2018) who claim that ICT can help students improve their language skills by doing language activities. The use of whiteboard electronically leads students to comprehend various genres provided by teachers. The teachers also give students an opportunity to discuss using e-reading material integrated with the electronic whiteboard (Hidayat, 2017). Therefore, this study showed that the implementation of the electronic whiteboard also gives the students success to understand the reading text and it can improve the students reading skils.

The use of the IWB enhanced pupils' ESL reading comprehension skills (Karthigesu and Mohamad, 2020). enhanced their classroom engagement, encouraged independent learning and promoted seriousness in reading. Integration of IWB also improved pronunciation and vocabulary among pupils. To conclude Research Question 1 (RQ1), IWB in the classroom enabled teachers to teach reading more effectively and maintain pupils' participation in the classroom. Despite the positive responses, teachers have to understand that learning is an active process, and the duration of pupils' engagement is only for a short period where teachers should come up with more challenging reading activities with the integration of IWB in order to maintain an optimum level of engagement and interest in learning.

\section{CONCLUSION}

This study aimed at finding out the effect of the electronic whiteboard on students' reading skills. It can be concluded that the electronic whiteboard was effective to teach reading skills. It was proven that the reading achievement in the experiment class was higher than in the control class. It showed that students get significant improvement in their reading skills by using electronic whiteboards. The researcher concluded that teaching in using electronic whiteboards can improve the students' understanding in reading skills. The researcher used electronic whiteboards in teaching reading skills, by using this media the researcher found that the students are good in understanding the text and improve their reading skills. Then, electronic whiteboards are the effective strategy to be used in the teaching and learning process because the researcher found any progress in students reading skills. In addition, the researcher is expected for the further researcher tobe conducted the research using the electroni whiteboard in the other area.

\section{ACKNOWLEDGEMENT}

This thesis would not be finished without any help from the others. Therefore, the researcher wishes to give his appreciation and thanks to all colleagues who have support and giving comments in any part of this article. Criticisms or suggestions from the readers very much expected to perfection this article. Furthermore, researchers hope this article can help readers to add scientific specialties. 


\section{REFERENCES}

Al-Saleem, A., \& Issa, B. (2012). The Interactive Whiteboard in English as a Foreign Language (EFL) Classroom. European Scientific Journal

Angelini, M. L., \& García-Carbonell, A. (2019). Developing English speaking skills through simulation-based instruction. Teaching English with Technology, 19(2), 3-20.

Ary, D, Jacobs, L and Sorensen, C, (2010). Introduction to Research in Education. Wadsworth: Cengage Learning.

Best, J. W. and Kahn, J. V. (2006) Research in Education (10th ed.). Boston: Pearson Education Inc.

Block, C. \& Israel, S. (2005). Reading First and Beyond: The Complete Guide for Teachers and Literacy Coaches. Thousand Oaks, CA: Corwin Press.

Bojovic, M. (2010). Reading Skills and Reading Comprehension in English for Specific Purposes. University of Kragujevac, Faculty of Agronomy Cacak, Serbia

Creswell, W, John. (2008). Educational Research: Planning, Conducting, and Evaluating Quantitative and Qualitative Research. United States of American Person Education

Elliot, C. (2003). Using a Personal Response System in Economics Teaching. International Review of Economics Education.

Haerazi, H., Utama, I., \& Hidayatullah, H. (2020). Mobile Applications to Improve English Writing Skills Viewed from Critical Thinking Ability for Pre-Service Teachers. International Journal of Interactive Mobile Technologies (IJIM), 14(07), pp. 58-72. DOI: http://dx.doi.org/10.3991/ijim.v14i07.11900

Hall, I., and Higgins, S. (2005). Primary School Students' Perceptions of Interactive Whiteboards. Journal of Computer Assisted Learning

Harmer, J. (2003). The Practice of English Language Teaching, 3rd Edition. London: Longman.

Hasan, Dhuha, Atallah, and Ibraheem, Rasha, Luay. (2018). The Impact of Using Interactive Whiteboard on Developing the Grammatical Competence of Iraqi EFL Learners. AL-Mustansiriyah Universit, College of Basic Education.

Hidayat, N. (2017). Developing E-reading materials for students at grade sevent. JEES (Journal of English Educators Society), 2(1), 33. https://doi.org/10.21070/jees.v2i1.676

Ibrahim, Mohamed, Al-Faki et al. (2014). Difficulties Facing Teachers in Using Interactive Whiteboards in Their Classes. American International Journal of Social Science Vol. 3 No. 2 March.

Ismail, H, S, J,K, \& Basuki. (2017). Improving the Students' Reading Skill Through Translation Method. Journal of English Education, 2(2,Dec), 124-131

Karthigesu, Kamini, and Mohamad, Maslawati. (2020). Primary School Teachers' Perception $s$ on the Integration of Interactive Whiteboard (IWB) during Reading Instructions. Faculty of Education, National University of Malaysia, Malaysia

Kose, N. (2006). Effects of Portfolio Implementation and Assessment Critical Reading on Learner Autonomy of EFL Students. Çukurova University The Institute Of Social Science English Language Teaching Department.

Le Breuilly, M. (2004). Benefits of The Interactive Whiteboard. Primary English Magazine, 9(5), 25-28.

Mustafa, F., Assiry, S. N., Bustari, A., \& Nuryasmin, R. A. (2019). The role of vocabulary elearning: Comparing the effect of reading skill training with and without vocabulary homework. Teaching English with Technology, 19(2), 21-43. 
Nicol, A. A. M., Owens, S. M., Le Coze, S. S. C. L., MacIntyre, A., \& Eastwood, C. (2018). Comparison of high-technology active learning and low-technology active learning classrooms. Active Learning in Higher Education, 19(3), 253-265. https://doi.org/10.1177/1469787417731176

Qader, R. O., \& Arslan, F. Y. (2019). The effect of flipped classroom instruction in writing: A case study with Iraqi Efl learners. Teaching English with Technology, 19(1), 36-55.

Prasojo, L. D., Mukminin, A., Habibi, A., Marzulina, L., Sirozi, M., \& Harto, K. (2018). Learning to teach in a digital age: ICT integration and EFL student teachers' teaching practices. Teaching English with Technology, 18(3), 18-32.

Serin, H. (2015). The Role of Interactive Whiteboard on Classroom Management. Department of Mathematics Teaching, Ishik University, Erbil, Iraq

Slay, H., Sieborger, I, \& Hodgkinson-Williams, C. (2008). Interactive whiteboards: Real beauty or just "lipstick"? Computers and Education.

Tanner, H., \& Jones, S. (2007). Learning from children about their learning with and without ICT using video-stimulated reflective dialogue. Swansea Institute of Higher Education

Teele, S. (2004). Overcoming Barricades to Reading a Multiple Intelligences Approach. Thousand Oaks, CA: Corwin Press.

Yunus, M. M., Salehi, H., \& Chenzi, C. (2012). Integrating Social Networking Tools into ESL Writing Classroom: Strengths and Weaknesses. English Language Teaching, 5(8), 4248. https://doi.org/doi:10.5539/elt.v5n8p42.

Zevenbergen, R., \& Lerman, S. (2008). Learning environments using interactive whiteboards: New learning spaces or reproduction of old technologies? Mathematics Education Research Journal. 